\title{
COMPARISON OF SPINAL CORD INJURIES IN FEMALES AND IN MALES, I979-I98I BASLE
}

By W. Kuhn, M.D., M.D.D., G. A. Zäch, M.D., Ph. KöChlin, M.D., and A. URWYLER, M.D.

Schweizerisches Paraplegikerzentrum, Im Burgfelderhof $40 \mathrm{CH}-4055$ Basel, Switzerland.

Summary. The statistics regarding age, marital status, nationality, paraplegic: tetraplegic ratio and causes of accident of the 92 female and 238 male patients in our Centre in the years I979-I98I show, in comparison to our own previous studies and those of other countries, the worldwide highest female-male rate of I:2.59. This is usually due to the higher occurrence of traffic accidents for women. The fact that in the age group below 30 years more women than men suffer from spinal cord injuries implies adapting rehabilitation and management to the specific needs of women.

Key words: Spinal cord injuries in female patients; Epidemiological evaluation; Implications for rehabilitation.

\section{Introduction and Methods}

THREE HUNDRED AND THIRTY patients suffering from spinal cord injuries were admitted to the Swiss Paraplegic Centre of Basle for treatment and rehabilitation in the period I979-I98I. These patients were analysed epidemiologically according to sex, age, marital status, nationality and aetiology of the accident. The question arose whether the expected differences of the analysed parameters are of such importance as to possibly justify different treatment and rehabilitation procedures according to the sex of the patient.

\section{Interpretation and Discussion of the Results}

\section{Female-male ratio}

Of the 330 patients, 92 were female and 238 male; this represents a femalemale ratio of $\mathrm{I}: 2.59$. A previous study in Switzerland (Gehrig and Michaelis, I968) for the period I960-1967 showed a ratio of I:4.96 (Table I). Similar to other countries (England, and Norway), which also have studies dating from different periods, one sees an increase in female spinal cord injuries. Surprisingly, however, one can find greatly varying femalemale ratios in different countries at the same time (Fukuoka, Lyon, North California); this could possibly derive from differences in the social, economic and cultural structures. 
TABLE I

Female to male ratio of patients with spinal cord injury: various reported injuries

\begin{tabular}{lllc}
\hline \multicolumn{1}{c}{ Study } & \multicolumn{1}{c}{ Site } & Period & $\begin{array}{c}\text { Female-Male } \\
\text { Ratio }\end{array}$ \\
\hline Frankel et al. (I968) & England & I95I-68 & $8 \cdot 59$ \\
Sutton et al. (I982) & North England & I975-79 & $4 \cdot 36$ \\
Kassa and McAdam (I967) & Norway & I949-57 & $6 \cdot 00$ \\
Gjone and Nordlie (I978) & Norway & I974-75 & $4 \cdot 95$ \\
Gehrig and Michaelis (I968) & Switzerland & I960-67 & $4 \cdot 96$ \\
This study & Basle & I979-8I & $2 \cdot 59$ \\
Jousse et al. (I967) & Toronto & I945-66 & $6 \cdot 85$ \\
Key and Retief (I970) & Cape Province & I963-67 & $8 \cdot 38$ \\
Kraus et al. (I975) & North California & I970-7I & $3 \cdot 70$ \\
Sutton (I973) & Brisbane & I962-7I & $7 \cdot 07$ \\
Tusji and Fujishama (I975) & Fukuoka & I969-74 & $9 \cdot 64$ \\
Minaire et al. (I978) & Lyon & I970-75 & $3 \cdot 70$ \\
Fine et al. (I979) & Alabama & I973-77 & $4 \cdot 28$ \\
Brown (I964) & New Zealand & I957-6I & 4.83 \\
\hline
\end{tabular}

\section{Age}

When comparing the age-structure of the whole Swiss population to the age-structure of our 330 patients one can see that morbidity for spinal cord injury is by far the highest in the female age group of under 20 years old, i.e. exactly double the morbidity of the same male age group (Table II).

TABLE II

Age group ratio

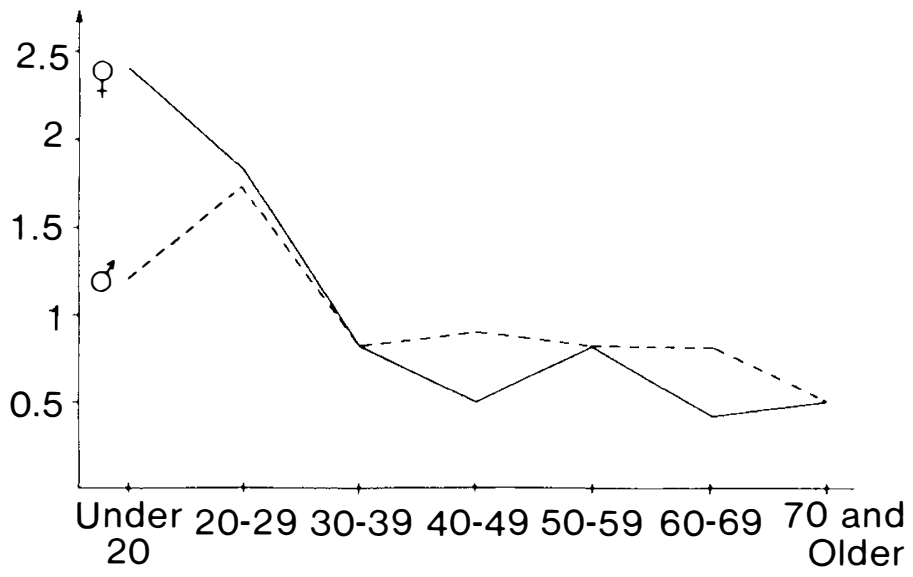

\section{Marital status}

The percentages of single, divorced, separated and widowed women are higher than those of the men. The higher percentage of single women ( 54.3 per cent women, 45.8 per cent men) is due to the above mentioned higher morbidity of women in the youngest age group (Table III). 
4. Nationality

The morbidity for spinal cord injury is practically identical for Swiss and foreign women. (About 20 per cent of the Swiss population are foreigners.)

5. Paraplegic:tetraplegic ratio

With regard to the level of spinal cord injury there is a remarkably higher percentage of female paraplegics than in the male group (Table IV).

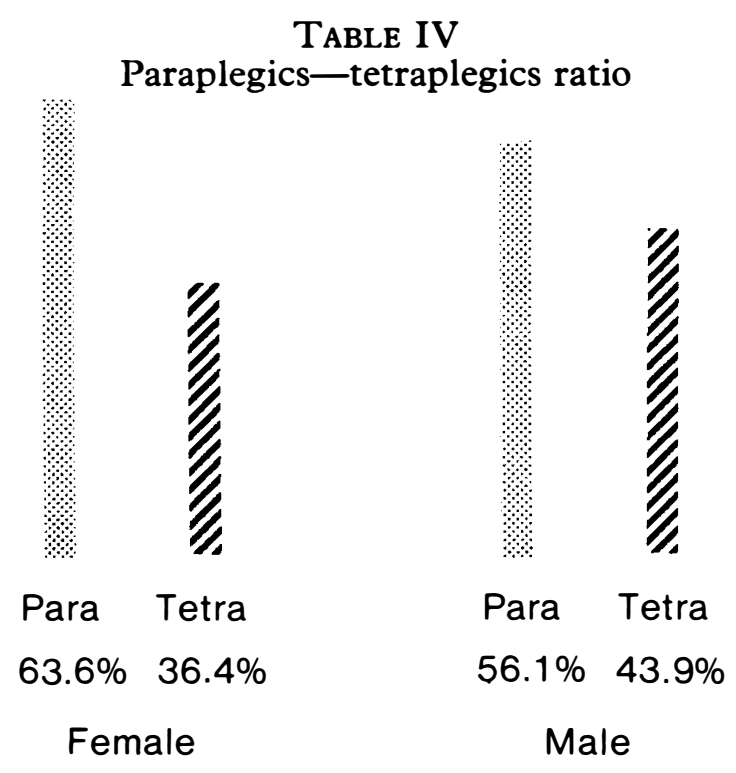

6. Cause of injury

The differences in percentage of the traffic, work accidents and suicide attempts are also remarkable (Table V). 
TABLE V

Causes of accident (overall)

$\%$

$\%$

अ.ł

48.9 Traffic $\quad 33.2$

8.7 Work 33.2

16.3 Sports $\quad 15.6$

\subsection{Suicides 2.6}

16.3 Other 15.6

Female

Male

Concerning road accidents there is a very high percentage of injured females both as car passengers as well as motorcycle passengers as compared with male passengers (car passengers 44.4 per cent to 25.3 per cent, motorcycle passengers II I per cent to I 3 per cent; Table VI).

\section{TABLE VI}

Traffic accidents

$\%$

Car:

\begin{tabular}{|c|c|c|c|}
\hline lı: & 22.2 & - Driver & 20.3 \\
\hline १ি & 44.4 & - Passenger & 25.3 \\
\hline & & Motorcycles: & \\
\hline 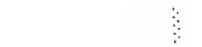 & 2.2 & - Driver & 30.4 \\
\hline ! & 11.1 & - Passenger & 1. \\
\hline 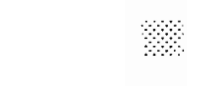 & 8.8 & $\begin{array}{c}\text { Bicycle/ } \\
\text { Motorbicycle }\end{array}$ & 3.9 \\
\hline ॠ & 8.8 & Pedestrian & \\
\hline & 2.2 & $\begin{array}{l}\text { Other } \\
\text { Traffic }\end{array}$ & \\
\hline
\end{tabular}

Female

Male

As can be expected, more men have severe accidents at work than do women; more women, however, fall from cherry trees during the cherry picking season (Table VII).

The number of sports which lead to spinal cord lesions is clearly smaller 
Falling From

\begin{tabular}{|c|c|c|}
\hline lা & 62.5 & Trees \\
\hline & 0 & Buildings \\
\hline ?. & 12.5 & Other \\
\hline lı. & 25 & $\begin{array}{c}\text { Other Work } \\
\text { Accident }\end{array}$ \\
\hline
\end{tabular}

Female

Male

for women than for men ( 4 to 8 ). Relatively more women than men, however, are injured when skiing or riding (Table VIII).

TABLE VIII

Accidents due to sport

$\%$

$\%$

१া

60

Skiing

27.1

20

Riding

8.1

6

Diving

0

Other Wate
Sports

16.2

0 Gymnastics

$8.1 \%$

0 Trampoline

5.4

o Mountaineer

$8.1 \%$

$0 \quad$ Deltagliding

2.7

$14 \quad$ Other Sports 24.3 


\section{Conclusions}

In Switzerland there is a steady increase in the number of women with spinal cord lesions (Gehrig and Michaelis, I968; Jenik et al., I982; Zäch, I977-82). Compared with other countries we have the highest femalemale ratio of $\mathrm{I}: 2.59$ for the period $1979-198 \mathrm{I}$.

The fact that 55.4 per cent of paraplegic and tetraplegic women are under 30 years old is due to the big increase in road accidents in which females are to a great extent involved as passengers.

A similar higher percentage of younger females is to be found in the female marital status; two-thirds of the female patients as opposed to one half of the male patients are unmarried, a fact which poses more problems for the re-integration of women than of men, (higher demands of self reliance or more dependance on help from outside the family).

The liability of spinal cord injury due to accidents at work is smaller for women than for men ( 8.7 per cent to 33.2 per cent). The percentage of falls from cherry trees among the female work accidents is, however, remarkably high in spite of all warnings given out every year in the cherry season.

In Switzerland there are now more deaths due to suicide than to road accidents. Female suicide attempts of appellatory nature constitute Io per cent of all accidents with spinal cord injuries. Understandably such patients must be looked after with special psychological care.

The steady increase of the number of women with spinal cord injuries implies more attention to specifically feminine problems in urological management and in social and vocational reintegration.

\section{RÉSUMÉ}

L'analyse statistique (âge, état civil, nationalité, relation paraplégiques/tétraplégiques et causes d'accidents) des 92 femmes et 238 hommes hospitalisés dans notre centre pendant les années I979-8I montre par rapport à nos propres travaux et à ceux d'autres auteurs un accroissement continuel du nombre de femmes paralysées avec un facteur de $1: 2,59$. Cette augmentation est surtout due à une incidence plus élevée des accidents de traffice. Le pourcentage élevé $(55,4 \%)$ des femmes de moins de 30 ans frappe en comparaison avec celui des patients masculins. Ceci implique une orientation accrue vers les problèmes spécifiquement féminins telqu'un management urologique adéquat ainsi que des efforts de réintégration au plan professionel et social de ces jeunes femmes qui de nos jours sont pratiquement indépendantes.

\section{ZUSAMMENFASSUNG}

Die statistische Analyse (Alter, Zivilstand, Nationalität, Verhältnis Paraplegiker/Tetraplegiker und Unfallursachen) der 92 weiblichen und 238 männlichen Patienten unseres Zentrums der Jahre I979-8 I zeigt verglichen mit eigenen und anderen Untersuchungen eine kontinuierliche Zunahme der querschnittgelähmten Frauen mit dem weltweit höchsten Faktor von I:2,59. Der Hauptanteil dieses Anstiegs liegt in der erhöhten Inzidenz für Verkehrsunfälle. Gegenüber den männlichen Patienten ist der hohe Anteil $(55,4 \%)$ der unter 30-jährigen Patientinnen auffallend, was eine vermehrte Orientierung hinsichtlich spezifisch weiblicher Probleme dieser Patientengruppe impliziert, wie vorallem adäquates urologisches Management, Reintegrationsbemühungen auf beruflicher und sozialer Ebene der heute weitgehend selbständigen jungen Frau.

\section{REFERENCES}

Brown, A. R. (1964). Paraplegia in New Zealand. Paraplegia, 2, I 53-I 55. 
Fine, P. R., Kuhlemeier, K. V., DeVivo, M. J., Stover, S. L. (i979). Spinal cord injury: An epidemiologic perspective. Paraplegia, 17, 237-250.

Frankel, A. L. et al. (1968). In: Minaire, P., Castanier, M., Girard, R., Bérard, E., Deidier, C. \& Bourret, J. (1978). Epidemiology of spinal cord injury in the Rhône-Alpes region, France, 1970-75. Paraplegia, 16, 76-87.

GeHRIG, R. \& Michaelis, L. S. (I968). In: Minaire, P., Castanier, M., Girard, R., Bérard, E., Deidier, C. \& Bourret, J. (I978). Epidemiology of spinal cord injury in the RhôneAlpes region, France, 1970-75. Paraplegia, 16, 76-87.

GJONE, R. \& NORDLIE, L. (I978). Incidence of traumatic paraplegia and tetraplegia in Norway: a statistical survey of the years 1974 and 1975. Paraplegia, 16, 88-93.

Jenik, F., KuHN, W. \& ZäCH, G. A. (I982). Social and vocational reintegration of paraplegic and tetraplegic patients in Switzerland. Paraplegia, 20, 65-70.

Jousse, A. T. et al. (1967). In: Minaire, P., Castanier, M., Girard, R., Bérard, E., Deidier, C. \& Bourret, J. (1978). Epidemiology of spinal cord injury in the Rhône-Alpes region, France, 1970-75. Paraplegia, 16, 76-87.

Kraus, J. F. et al. (I975). In: Minaire, P., Castanier, M., Girard, R., Bérard, E., Deidier, C. \& Bourret, J. (1978). Epidemiology of spinal cord injury in the Rhône-Alpes region, France, 1970-75. Paraplegia, 16, p. 76-87.

Key, A. G. \& RETIEF, P. J. M. (I970). In Minaire, P., Castanier, M., Girard, R., Bérard, E., Deidier, C. \& Bourret, J. (1978). Epidemiology of spinal cord injury in the Rhône-Alpes region, France, 1970-75. Paraplegia, 16, p. 76-87.

Kraus, et al. (1975). In: Minaire, P., Castanier, M., Girard, R., Bérard, E., Deidier, C. \& Bourret, J. (I978). Epidemiology of spinal cord injury in the Rhône-Alpes region, France, I970-75. Paraplegia, 16, 76-87.

Minaire, P., Castanier, M., Girard, R., Bérard, E., Deidier, C. \& Bourret, J. (i978). Epidemiology of spinal cord in the Rhône-Alpes region, France, 1970-75. Paraplegia, I6, 76-87.

Sutron, N. G. (1973). Injuries of the Spinal Cord. The Management of Paraplegia and Tetraplegia. Butterworths: London, p. I85.

Sutton, R. A., Bentley, M., Castree, B., Mattinson, R., Pattinson, J. \& Smith, R. (I 982). Review of the social situation of paraplegic and tetraplegic patients rehabilitated in the Hexham Regional Spinal Injury Unit in the North of England over the past four years. Paraplegia, 20, $7 \mathrm{I}-79$.

Tusji \& FujIShama, S. (1975). In: Minaire, P., Castanier, M., Girard, R., Bérard, E., Deidier, C. \& Bourret, J. (1978). Epidemiology of spinal cord injury in the Rhône-Alpes region, France, 1970-75. Paraplegia, 16, 76-87.

Z̈̈CH, G.A. (I977). Jahresstatistik I976 Schweizerisches Paraplegikerzentrum Basel.

ZäcH, G. A. (I978). Jahresbericht I977. Bürgerspital Basel, Schweizerisches Paraplegikerzentrum. Drukerei Schraner und Co, 8048 Zürich, 9-I6.

ZäCH, G. A. (1979). Jahresstatistik I 978 Schweizerisches Paraplegikerzentrum Basel.

ZäcH, G. A. (I980). Jahresstatistik I979 Schweizerisches Paraplegikerzentrum Basel.

ZäCH, G. A. (I98I). Jahresstatistik I980 Schweizerisches Paraplegikerzentrum Basel.

Z ̈̈̈H, G. A. (1982). Jahresbericht I981. Offizielles Organ der Schweizerischen Paraplegikerstiftung, Paraplegie 22, Juni 1982, 6. Jahrgang, I3-19. 